управління i місцевого самоврядування, прискорити розгляд законопроектів про Кабінет Міністрів України, про центральні органи виконавчої влади, про адміністративно-територіальний устрій, нової редакції Закону «Про місцеве самоврядування в Україні» (а можливо, й Муніципального кодексу), щоб потім логічно продовжити конституційне регулювання відповідно до потреб поступального розвитку країни, адже задоволення потреб і досягнення цілей громади фактично означає функціонування та розвиток колективу людей, а відповідно і європейський розвиток всієї держави.

1. Конституція України

\title{
Література:
}

2. Адміністративне право України. Повний курс: підручник / Галунько В. Діхтієвський П., Кузьменко О., Стеценко С. та ін. Херсон: ОЛДІ-ПЛЮС, 2018.446с. ISBN 978-966-289-184-3

3. Мальковская И. А. Трансформация государства и эволюция публичного администрирования в условиях глобализации (актуализация европейского опыта для России) / И. А. Мальковская // Вестн. Рос. ун-та дружбы народов. - 2006. - № 8. - С. 27-43. - (Серия: Политология).

DOI https://doi.org/10.30525/978-9934-588-92-1-64

\section{ПРАВОВА ХАРАКТЕРИСТИКА ВUG ВОUNТY (БАГ БАУНТІ) ЯК ПЕРСПЕКТИВНОГО МЕХАНІЗМУ ЗАБЕЗПЕЧЕННЯ ІНФОРМАЦІЙНОЇ БЕЗПЕКИ}

\author{
Мельянков В. С. \\ студент другого року навчання магістратури \\ Інституту права
}

Київського національного університету імені Тараса Шевченка м. Київ, Україна

У наш час вже навряд можна здивувати когось, зауваживши, що інформація - один із найцінніших ресурсів сьогодення. Бажання володіти цінними ресурсами, у свою чергу, є природнім прагненням людини, яке може бути задоволено як правомірним, так $\mathrm{i}$ неправомірним шляхом. За таких умов, питання захисту інформації $\epsilon$ 
настільки ж важливим, як і сама інформація. Але як забезпечити іiі належний захист за умови, коли будь-хто може отримати доступ до онлайн-ресурсу, i точно невідомо, чи $\epsilon$ така особа, наприклад, потенційним клієнтом, або ж має менш приємні наміри?

Баг баунті (Bug Bounty) пропонує достатньо лаконічну відповідь на таке питання - необхідно шукати шляхи правомірної співпраці із особами, які володіють навичками, необхідними для отримання несанкціонованого доступу та тестування інформаційних ресурсів, 3 метою заохочення правомірної реалізації таких навичок. Можливість повідомлення про виявлену вразливість та отримання за це винагороди вбачається більш безпечною альтернативою розповсюдженню неправомірно отриманій інформації.

У той же час, застосування такого підходу в Україні викликає ряд питань, які і зумовлюють актуальність теми: якою $є$ правова природа Баг баунті? Якими правовими нормами регулюється Баг баунті? Чи існують особливі вимоги щодо організації Баг баунті для наприклад, суб'єктів владних повноважень?

Пошук відповідей на ці питання було взято за мету, і відповідно до неї було сформовано наступні завдання:

1. Визначення правової природи Баг баунті відповідно до положень вітчизняного законодавства;

2. Аналіз організаційно-правових особливостей застосування Баг баунті суб'єктами владних повноважень.

Проблематику забезпечення інформаційної безпеки досліджували такі вітчизняні науковці, як, Берездецький Ю.М., Пальчик М.Л., Дубов Д.В., Бойко В. О., Гнатюк С. Л., Заярний О.А., Ісакова Т. О., Ожеван М. А., Покровська А. В.

Правова природа. Хоча питанню Баг Баунті присвячено певну увагу в україномовних публікаціях, безпосереднє визначення терміну надається вкрай нечасто. Виходячи 3 досвіду проведення Баг баунті такими платформами як, зокрема, Prozorro, Grammarly, Google, Facebook, на суб'єктивне переконання, можна надати наступне визначення Баг баунті: це спосіб проведення тестування захищеності інформаційних ресурсів за дозволу суб'єкта, відповідального за безпеку таких інформаційних ресурсів, що здійснюється заздалегідь невизначеним колом осіб за винагороду у випадку виявлення та повідомлення про виявлену вразливість безпеки такого інформаційного ресурсу.

У свою чергу, інформаційні ресурси вбачається за доцільне розуміти у значенні, наданому Заярним О.А: Інформаційні ресурси масиви документів, бази та банки даних, різноманітні архіви, 262 
бібліотеки, музейні фонди, які містять, відомості, знання, зафіксовані на доступних носіях інформації $[4$, с. 8$]$.

На суб'єктивне переконання, Баг баунті доцільно розглядати як публічну обіцянку винагороди. Так, відповідно до положень ч. 1 ст. 1144 Цивільного кодексу, особа має право публічно пообіцяти винагороду (нагороду) за передання ій відповідного результату (передання інформації, знайдення речі, знайдення фізичної особи тощо) [1]. Визначення меж інформаційних ресурсів, захищеність яких має бути протестована, можна розцінювати як зміст завдання (у розумінні ст. 1145 Цивільного кодексу), а виплата винагороди і без спеціального на те зазначення $€$ правовим наслідком виконання завдання за загальним правилом (відповідно до ст. 1148 Цивільного кодексу).

Варто зауважити, що окрім публічності, проведення Bug bounty, зазвичай, характеризується забезпеченням певного ступеня анонімності осіб, які повідомляють про виявлену вразливість. Так, Правила та умови тестувальника (Finder Terms And Conditions) HackerOne, однієї 3 найвідоміших платформи для організації проведення Баг баунті, передбачають, що тестувальник може використовуючи псевдонім. Однак, щоб отримати право на винагороду, тестувальник повинен надати HackerOne точну, повну та актуальну інформацію про адресу, податковий номер та будь-яку іншу інформацію, яка допоможе платформі надіслати тестувальнику винагороду. Якщо ж особа не хоче надавати такі відомості - передбачена можливість направлення винагороди буде здійснене на користь благоднійної організації, обраної платформою [7].

Якщо ж особа, яка має здійснювати тестування, чітко визначена, то вбачається, що такі відносини доцільно характеризувати не як Bug bounty, а як послугу з комп'ютерного аудиту. Послуга з комп'ютерного аудиту також активно застосовується у вітчизняній практиці, згадується Єдиним закупівельним словником [3], втім, за своєю природою $є$ окремим явищем, а тому потребує окремого дослідження.

Особливості застосування Баг баунті суб'єктами владних повноважень. Першу програму Баг баунті на постійній в межах публічного сектору було здійснено стосовно платформи Prozorro. Цікавою особливістю тут постає те, що правовою основою для проведення Баг баунті виступає «Договір приєднання про надання послуг з пошуку вразливостей Електронної системи закупівель» [5]. Іронічно, але уваги заслуговує таке правове оформлення зокрема і 3 точки зору проведення публічних закупівель, що регламентується Законом України «Про публічні закупівлі» [2]. Відповідно до згаданого договору, координатором (тобто особою, із якою тестувальник укладає 
договір) виступає не безпосередньо ДП «ПРОЗОРРО», а Громадське об’єднання «Рескілл». Зазначене Громадське об'єднання, у свою чергу, уклало договір з ДП «ПРОЗОРРО» $з$ надання послуг щодо реалізації проекту «Electronic Procurement System Bug Bounty Program», чому передувала процедура закупівлі [6]. Таким чином, організатором проведення Баг баунті виступає не ДП «ПРОЗОРРО» безпосередньо, а стороння громадська організація, при цьому залучення тестувальників (або ж «хантерів» як їх названо у перелічених вище договорах) не потребує ініціації процедури закупівлі, навіть при тому, що вони $є$ надавачами послуг.

Вбачається, що при застосуванні подібного підходу, необхідно враховувати, зокрема, наступне:

1. Строки та розмір винагороди. Необхідно враховувати, що достатньо важко оцінити, скільки вразливостей буде виявлено. Безстрокове проведення Баг баунті у цьому контексті $є$ найризикованішим варіантом з точки зору витрат, але, безумовно, ефективним 3 точки зору забезпечення кіберзахисту;

2. Можливість моніторингу винагород. Оскільки мова йде про проведення Баг баунті, що ініціюється суб'єктом владних повноважень, але координується стороннім суб'єктом, доцільно регламентувати процедуру контролю за тим, як такий сторонній суб'єкт здійснює оцінку виявлених вразливостей та виплати. Таке вбачається за необхідне як з точки зору зменшення корупційних ризиків, так і з точки зору забезпечення права тестувальника на отримання винагороди;

3. Ефективність виправлення та публічне повідомлення про виявлені вразливості Координатором. Необхідно також забезпечити швидке виправлення виявлених вразливостей, адже без цього проведення такого заходу не матиме сенсу, а тестувальники витрачатимуть час на підготовку повідомлень про вразливості, що уже були виявлені.

\section{Література:}

1. Цивільний кодекс України від 16.01.2003 № 435-IV / Верховна Рада України. URL: https://zakon.rada.gov.ua/laws/show/435-15/print (Дата звернення: 26.10.2020).

2. Закон України «Про публічні закупівлі» від 25.12.2015 № 922VIII / Верховна Рада України. URL: https://zakon.rada.gov.ua/laws/ show/922-19\#Text (Дата звернення: 26.10.2020).

3. Розділ 72000000-5 ДК 021:2015 Єдиний закупівельний словник URL: https://dk21.dovidnyk.info/index.php?rozd=7215 (Дата звернення: 26.10.2020). 
4. Заярний О.А. Інформаційна сфера як об'єкт адміністративноправової охорони: деякі доктринальні та нормативні аспекти. Журнал східноєвропейського права. 2016. № 23. С. 18-31. URL: http://easternlaw.com.ua/wp-content/uploads/2016/01/zaiarnyi_23.pdf (Дата звернення: 26.10.2020).

5. Договір приєднання про надання послуг з пошуку вразливостей Електронної системи закупівель Громадського об’єднання «РЕСКІЛЛ». URL: https://docs.google.com/document/d/1LKfr6em6ishurqug42kdq4VaIt8RrZ6/edit (Дата звернення: 26.10.2020).

6. Договір № 00000306/Г з надання послуг щодо реалізації проекту «Electronic Procurement System Bug Bounty Program». URL: https://www.dzo.com.ua/tenders/7036537 (Дата звернення: 26.10.2020).

7. HACKERONE FINDER TERMS AND CONDITIONS Effective Date: June 1, 2020. Url: https://www.hackerone.com/terms/finder (Дата звернення: 26.10.2020).

DOI https://doi.org/10.30525/978-9934-588-92-1-65

\title{
ON THE ISSUE OF GRANTING CONCENTRATION PERMISSIONS TO BUSINESS ENTITIES UNDER THE LAWS OF UKRAINE
}

\author{
Pasichnyk V. V. \\ Attorney at law, \\ Graduate Student \\ Informatics and Law Research Institute of the National Academy \\ of Legal Sciences of Ukraine \\ Kyiv, Ukraine
}

In order to preclude monopolization of commodity markets, abuse of monopoly (market) power, restriction on competition and prevention of unfair competition in Ukraine, the legislator enshrined the obligation of business entities to apply to the Antimonopoly Committee of Ukraine for concentration permission, in particular, for direct or indirect procurement, acquisition of ownership in other way or receipt of equity (stocks and shares) in trust which ensures the achievement or excess of 25 or 50 percent of the votes in the supreme management body of the business entity.

The issue of obtaining permission of the Antimonopoly Committee of Ukraine for concentration, i.e. for acquisition by a business entity of a 